\title{
Variation of the hydrological regime of Bele-Shira closed basin in Southern Siberia and its reflection in the radial growth of Larix sibirica
}

Elena A. Babushkina ${ }^{1 a^{*}}$, Liliana V. Belokopytova ${ }^{1 b}$, Alexi M. Grachev ${ }^{2}$, David M. Meko ${ }^{3}$, Eugene A. Vaganov ${ }^{4,5}$

${ }^{1}$ Khakass Technical Institute, Siberian Federal University, 27 Shchetinkina St., Abakan 655017, Russia.E-mail: (a) <babushkina70@mail.ru>,(b) <white_lili@mail.ru>

${ }^{2}$ Institute of Geography of the Russian Academy of Sciences, 29 Staromonetniy Pereulok, Moscow 119017, Russia.

${ }^{3}$ Laboratory of Tree-ring Research, The University of Arizona, 1215 E. Lowell Street, Box 210045, Tucson, AZ, 85721, USA.E-mail: 〈dmeko@ltrr.arizona.edu>

${ }^{4}$ Siberian Federal University, Pr. Svobodniy 79, Krasnoyarsk 660041, Russia. E-mail: <eavaganov@hotmail.com>

${ }^{5}$ V. N. Sukachev Institute of Forest, Siberian Branch of the Russian Academy of Sciences, Akademgorodok, 50/28, Krasnoyarsk 660036, Russia

Corresponding author. E-mail address: < babushkina70@mail.ru >, tel. +7(3902)22-53-55.

\begin{abstract}
This study analyses dynamics of the hydrological regime of Bele-Shira closed basin and evaluates the potential for using radial growth of Siberian larch (Larix sibirica) for its assessment. We investigated the relationships between different characteristics of the water level variation of Lake Shira, precipitation amount and long-term regional chronologies developed from 56 living trees and 32 dead trees on three sites across this basin. Graphical and correlation analysis indicate that the interannual change (June minus previous June) of the water level of Lake Shira is strongly positively related to the annual sum of precipitation from July to June and the radial growth of larch. It was shown that this hydrological characteristic integrates the current dynamics of the regional precipitation and moisture regime as a whole of the Bele-Shira closed basin on interannual and decadal scales. The water level of Lake Shira fluctuates on a multi-year timescale in synchrony with the cumulative sum of the tree-ring chronology and also has strong positive long-term trend, probably driven by the continual groundwater inflow from neighboring Lake Itkul. Delayed relationships of precipitation and radial growth with the Lake Shira level change are interpreted with reference to a water-balance model of the closed basin. Results offer the possibility of reconstructing interannual and decadal variation of the hydrological regime during the last few centuries through regression models using tree-ring chronologies or the dynamics of climatic variables recovered from them.
\end{abstract}

Keywords Dendrohydrology; Southern Siberia; Hydrological regime; Closed basin; Radial growth; Larix sibirica.

\section{Length of the manuscript}

The number of words: 5540

Number of tables: 2

Number of figures: 6 


\section{Introduction}

2 Precipitation delivery to the interior regions of continents can vary greatly over short distances

3 due to the importance of typically spotty convective storms to warm-season precipitation and to

4 the spatial variability of moisture sources and the steering influence of topography on storms.

5 Consequently, the hydrologic regime of such regions can be difficult to characterize with sparse

6 station instrumental climate records. This is especially true for semiarid regions (Bradley 2009),

7 where station meteorological data may poorly reflect the dynamics of the regional water balance.

8 On the other hand, the hydrological regime of lakes and other water bodies is inextricably linked

9 to regional climate, and water bodies serve as natural integrators of moisture availability within

10 their catchments (Shnitnikov 1969; Maksimov 1989; Wang et al. 2012). Parameters traditionally

11 considered for rivers are integrated volume of discharge and discharge rate averaged over some

12 period (Meko et al. 2001; Matskovsky et al. 2010; Meko and Woodhouse 2011). The main hydrological property of a lake is its water level. It should be noted, that the lake water level for a flow-through lake generally reflects the current climatic conditions in the catchment basin (e.g. Meko 2006; Quinn and Sellinger 2006). For a closed-basin lake the water level integrates the dynamics of moisture availability for the entire period of the lake existence. Therefore instead of the water level itself, the change in water level $(\Delta L)$ over a certain period reflects current climatic conditions. This parameter, $\Delta L$, serves as a differential, dynamic characteristics of the hydrological regime (e.g. DeRose et al. 2014).

Long records are essential to studying the dynamics of hydrologic regimes, and a lack of long instrumental records is often compensated for by using indirect data sources. Many hydrologic studies have applied tree-ring chronologies from arid and semi-arid habitats, where water is a vital parameter for ecosystem functioning. The water balance of the vegetation is subject to similar climatic influences as the water balance of a hydrologic basin. Precipitation is the main source of moisture for vegetation and in semiarid regions most of the water is 
1

2

3

4

consumed by evapotranspiration. A network of tree-ring chronologies integrates moisture availability conditions over a particular collection area and thus can be used to assess the dynamics of the hydrological regime of a basin (e.g. Meko and Woodhouse 2011; DeRose et al. 2014). However it should be noted, that the relationships between the hydrological variables and the incremental growth of woody plants depends on many factors. These factors range from the type of the water body to the distribution of precipitation throughout the year, and cannot be considered in isolation from the phenology of the plants. Therefore the relationships between the hydrological characteristics and woody plant growth should be evaluated individually for each catchment area. While many dendrohydrology studies have focused on large basins (Meko and Woodhouse, 2011), attention has shifted in recent years to relatively small, local watersheds (Biondi and Strachan, 2012). Small watersheds present a challenge, especially in areas with uneven terrain and variable climatic conditions. We can assume that the size of the catchment area affects the relationship between climate and the hydrological regime: for a small catchment area there should be a smaller lag in hydrologic responses (e.g., lake levels) than for large basin. Also there should be a more significant impact of current climate fluctuations.

In this study the objective was to evaluate the potential of using radial growth chronologies (tree ring widths - TRW) from coniferous trees in the continental climate of Southern Siberia in order to assess the dynamics of a watershed moisture regime. The geographical framework for the study is the Bele-Shira closed basin, situated between the major drainages of the Yenisei and Ob Rivers. Our specific goals were as follows: 1) obtaining long tree-ring chronologies for Siberian larch (Larix sibirica Ledeb.) and investigating their response to changes in moisture regime at annual and longer timescales, 2) examining the possibility of using those chronologies for assessing the components of the hydrological regime of a closed basin, and 3) identifying the more general prospects and limitations of the dendrochronological method of the evaluation of past changes in the hydrological regime of closed basins. 


\section{Methodological approach}

\section{Hydrological and climatic characteristics of the study area}

3 The Bele-Shira closed basin (Fig. 1) covers an area of approximately $3600 \mathrm{~km}^{2}$ in the inter-

4 stream area between the Chulym River and Yenisei River. The basin includes the watersheds of

5 Lake Bele, Lake Itkul, and Lake Shira, as well as several small lakes. Elevation ranges from

$6348 \mathrm{~m}$ above sea level at Lake Shira to $1000-1200 \mathrm{~m}$ at the sources of the main rivers on the

7 northern macroslope of Batenevskiy Ridge. The first of these rivers is the Tuim River, which

8 flows into Lake Bele and has a seasonal passage to the watershed of Lake Itkul through an

9 effluent channel into the Karysh River. The second is the Son River, which flows directly into

10 Lake Shira. The third is the Karysh River, which flows into Lake Itkul. The water in the enclosed

11 lakes Shira and Bele is saline with concentrations of dissolved salts of 12-31 and 9-14 grams per

12 liter, respectively. At the same time the water of Lake Itkul is fresh $(0.6-0.7 \mathrm{~g} / \mathrm{l})$ due to its seasonal outflow through the Tushino Stream into the Tuim River, as well as to underground water outflow into Lake Shira, which is about $4 \mathrm{~km}$ away and about $100 \mathrm{~m}$ lower (Savitchev et al. 2015). Through these various pathways all three major watersheds of the Bele-Shira closed basin are linked into a single hydrological system.

The longest series of instrumental data (1936-2012) summarizing the main hydrological characteristics of the Bele-Shira basin are measurements of Lake Shira water level from a gage at $54^{\circ} 30^{\prime} \mathrm{N} 90^{\circ} 10^{\prime} \mathrm{E}$. In this paper we used the average monthly values of the water level, $L$, in centimeters above the observation point mark (348.19 $\mathrm{m}$ a.s.1.), and several derived series (Fig. $2 \mathrm{a}, \mathrm{c})$. The first of these is the 12-month change, or first difference, $\Delta L$, of water level for a given month of year. Two detrended water-level series were also computed: $L_{\text {res } 1}$ and $L_{\text {res } 3}$, which are departures from first-order and third-order polynomials (linear and cubic trend) fit to $L$ for a specific month of the year. The fitted trend lines themselves are denoted $L_{1}$ and $L_{3}$. Time plots of 
1

2

3

4

these various water level series for the month of June illustrate the trends and variability (Fig. 2a, c).

Also, for analysis of the intra-annual fluctuations of lake water-level we made use of monthly discharge data for the Tuim River $\left(54^{\circ} 20^{\prime} \mathrm{N}, 8^{\circ} 56^{\prime} \mathrm{E}\right)$ for the period $1970-2012$, and for the Son River (54²7' N, 90²2' E) for the periods 1967-1997 and 2005-2012 (Fig. 2b). Monthly river discharge is bimodal, with peaks in April and July. The discharge rate decreases in the winter months due to precipitation falling as snow and to freezing of the river itself. The April maximum in discharge is due to melting of ice and snow, i.e., the contribution of coldseason precipitation, whereas the July maximum is associated with the warm-season maximum in annual precipitation. In response to these inputs, the water level in Lake Shira increases on average from April until August, and decreases during the cold months.

According to detailed work on the hydrology by Savichev et al. (2015), Lake Shira is completely enclosed (no outflow). Given the relationship between the three main watersheds of the lakes of the Bele-Shira basin, we can express the water balance of Lake Shira with the following simplified equation, based mostly on equations given in Shanahan et al. (2007) and Giadrossich et al. (2015), and information in Savichev et al. (2015):

$$
\Delta V=\Delta L * A(L)=\left(L_{\mathrm{t}}-L_{\mathrm{t}-1}\right) * A(L)=P_{0}-E_{0}+Q_{\mathrm{I}}(P, E)+Q_{\mathrm{S}}(P, E)+Q_{\mathrm{g}}(P, E)+W
$$

where $\Delta V$ is change of water volume in the Shira Lake; $A$ is surface area of the Lake Shira, which depends on its level, and due to lack of instrumental measurements is assumed approximately constant; $P_{0}$ is precipitation on the surface of Lake Shira; $E_{0}$ is evaporation from this surface; $Q_{\mathrm{I}}, Q_{\mathrm{S}}$ and $Q_{\mathrm{g}}$ are inflows from Lake Itkul (underground), from the Son River and from the rest of the watershed area of Lake Shira (underground), which depend on precipitation $(P)$ and evapotranspiration $(E)$ in the respective basins; and $W$ is wastewater discharge. According to Savichev et al. (2015), $W$ is the least significant of the inflow sources. It should be noted that water sources for human use are the Tuim River and Lake Itkul, which belong to the 
1

same closed basin. The question of how much has the human use changed the amount of water reaching Lake Shira since 1936 should be researched further using available records.

Instrumental data to characterize the climatology of the basin were obtained for the Shira weather station $\left(54^{\circ} 30^{\prime} \mathrm{N}, 8^{\circ} 56^{\prime} \mathrm{E}\right.$-- synoptic code \# 29756) from the Federal Service for Hydrometeorology and Environmental Monitoring of the Russian Federation. These data consisted of monthly average air temperature for the period 1966-2012 and monthly precipitation for 1936-2012. The climate of the basin is strongly continental and moderately cold (Alisov 1956). The average annual temperature at station Shira is about $+1^{\circ} \mathrm{C}$, and the beginning of the growing season (the transition to air temperature above $+5^{\circ} \mathrm{C}$ ) on average occurs at the end of April (Fig. 3). Average annual precipitation is $301 \mathrm{~mm}$ with a pronounced summer maximum: 86-94\% of precipitation falls during the period from April to October, with the largest amount in July. It should be noted that the regional climate fluctuations are characterized by the typical continental course of temperature and precipitation during the warm season - that is, the alternation of hot and dry periods with contrasting cool and wet periods (Bazhenova and Tyumentseva 2010).

To assess the hydrothermal regime of the study area during the warm period (May to September) we used the Selyaninov hydrothermal coefficient (HTC), introduced by G. T. Selyaninov (1958) as an agroclimatic indicator of moisture availability to plants. The HTC is calculated as the ratio of precipitation amount to the sum of average daily temperatures above $10^{\circ} \mathrm{C}$ divided by ten. In the study area the HTC has a stronger relation with plant growth than other commonly used indices, for example, the Palmer drought severity index (Palmer 1965). HTC monthly values, especially for July and September, in the study area are characterized by high interannual variability. This is mainly due to the fluctuations in precipitation and the negative correlation of temperature with precipitation. The range of monthly mean HTC values computed for the whole observation period (1966-2012) is from 1 to 1.3 , and is typical of semiarid conditions (the lower limit of the forest). 


\section{Composition of the tree-ring chronologies}

2 Wood samples of Larix sibirica were collected from sparse stands at the lower limit of the forest

3 in the southern part of the basin (Fig. 1). Healthy living trees of various ages (for better cross-

4 dating) with no close neighbors were selected for sampling. The sites are located at a distance of

$5 \quad$ 1-3 km from the Tuim River and Son River at elevations of 550-650 m above sea level and have

6 the following coordinates: TUIM (54ำ $\left.19^{\prime} \mathrm{N}, 89^{\circ} 55^{\prime} \mathrm{E}\right)$, SON1 $\left(54^{\circ} 22^{\prime} \mathrm{N}, 90^{\circ} 22^{\prime} \mathrm{E}\right)$ and SON2

$7 \quad\left(54^{\circ} 19^{\prime} \mathrm{N}, 90^{\circ} 19^{\prime} \mathrm{E}\right)$. Micro-sites conditions and associated vegetation are similar at all three

8 sites. Only living trees were sampled at SON1 and SON2: 15 and 10 trees, respectively, were

9 cored at breast height $(\sim 1.3 \mathrm{~m})$ by Swedish increment borer. One core was taken from each tree.

Cores from 31 living trees and cross-sections from 32 dead trees were sampled at TUIM. The

cross-sections were taken from stumps by chainsaw at a height of 0.3-0.6 m. Samples from dead trees extended the local living-tree TUIM chronology by 70 years. Transportation and primary processing of samples followed standard procedures in dendrochronology (Cook and Kairiukstis 1990).

Tree ring widths (TRW) were measured to an accuracy of $0.01 \mathrm{~mm}$ on a LINTAB 5

instrument using the software package TSAP Win (Rinn 2011). The crossdating, or determination of the calendar year of each annual ring, was determined by visual patternmatching, and was checked by cross-correlation analysis using program COFECHA (Holmes, 1999). To extract the common external signal, we standardized and converted the measured widths to chronologies using program ARSTAN (Cook and Krusic 2005). The first step was removal of the age trend, calculated as a $67 \%$ cubic smoothing spline, or a spline with a frequency response of 0.5 at $67 \%$ of the series length (Cook and Peters 1981). Measured ring widths were then divided by the value of the fitted spline curve to obtain dimensionless indices. These indices were subsequently averaged over series to obtain the standard (std) generalized chronologies. For a so-called residual (res) form of the chronologies, the same procedure was followed, except that first-order autocorrelation was removed from the individual index series 
1 before averaging over series (Cook and Kairiukstis 1990). The quality of the resulting std and res

2 chronologies was checked with conventional dendrochronology statistics: inter-series

3 correlation $(\bar{R})$, expressed population signal (EPS, averaged and in a 50-year-moving window),

4 and mean sensitivity $(S)$ for the full length of chronology (Cook and Kairiukstis 1990, Wigley et

5 al. 1984, Fritts 1976). For the standard regional (averaged over all samples) chronology we also

6 computed a measure of integral larch growth in each year as the cumulative sum of Z-scores

7 (mean of zero and standard deviation of one) of that chronology over the interval from the

8 beginning of the chronology up to the specified year.

9 The strength of relationship between pairs of time series was measured by the Pearson 10 correlation coefficient (Wilks 1995). Linear regression (Wilks 1995) was used to assess trend in 11 individual time series, and to estimate the strength of relationship between lake-level variables

12 and other variables for simplicity of modeling (we also preliminary checked different non-linear

13 regression models, and they didn't show significantly higher values of $\mathrm{R}^{2}$ then linear model).

14 Decadal fluctuations in time series were summarized by smoothing series with a cubic smoothing spline of specified flexibility (Cook and Peters 1981). 


\section{$1 \quad$ Results}

\section{Tree-ring chronologies}

3 The sampled trees provide time coverage of TRW for the period 1719-2013. High correlation of

4 the TUIM core chronology with the TUIM cross-section chronology (Supplementary Table S1)

5 suggested combining these series into one TUIM chronology. While correlations between SON1

6 and SON2 sites chronologies are lower, we also combined these series into one chronology

7 because growing conditions at these sites are similar and pointer years (years of exceptionally

8 high or low growth) at the two sites are identical. Relatively high correlations between the

9 chronologies TUIM and SON further justify combining them into a regional SHIRA chronology

10 (Fig. 4). The statistics of the local and regional chronologies $(\bar{R}>0.5$, EPS $>0.85$ and for most

11 chronologies $S>0.3$ ) support a strong common growth signal across samples, and suggest that

12 chronologies are suitable for dendroecological analysis (Table 1). By the start of the period used

13 in this study for assessing the hydrologic signal in tree rings (1936), the sample size of the

14 regional chronology exceeds 67 radii and the same number of trees.

\section{Relationships between tree-ring chronologies, climate and hydrology}

Correlation analysis revealed significant dependence of radial growth of larch on temperature and precipitation (Fig. 5). Precipitation is positively correlated with radial growth in the second half of the previous growing season and in the first half of the current growing season, as well as in November. The response to temperature is negative, weaker than the response to precipitation and significant only for September of the previous year and May of the current year. The hydrothermal coefficient (HTC) is positively correlated with TRW. Significant correlation coefficients in this case are observed for the period July-September of the previous year. We also considered aggregated months in the first and in the second half of the growing season. The most significant correlations of the larch increment growth with precipitation and HTC are observed 
1 for the periods July-September of the previous year and May-June of the current year. For

2 temperature the correlation is significant for August-September of the previous year and May-

3 July of the current year. Correlation increases with aggregation over months, such that a

4 maximum response of TRW to climate parameters of moisture availability is observed for the

5 12-month annual period that starts in July of the previous year and ends in current June.

The level of Lake Shira does not have a positive linear relationship with either tree-ring

7 chronologies or precipitation. Subtraction of the long-term trend from lake-level does not substantially change this picture regardless of the type of function (linear or third-degree polynomial). On the other hand, the first-difference $\Delta L_{\text {June }}$, or difference of the monthly average lake level for current June and June of the previous year, has a strong positive relationship with the total precipitation for the 12-month period from previous July until current June and also with the TRW chronologies of larch. Correlation analysis for various aggregated months showed that for both $\Delta L$ and precipitation highest correlation with TRW is for the period ending in June. Correlation coefficients of the regional standard chronology with the 12-month $\Delta L$ reach values of $0.61,0.64$ and 0.63 for periods ending in May, June, and July respectively (Table 2). residual chronologies (Table 2 and Fig. 6a, b).

First-order autocorrelation of $\Delta L\left(\mathrm{r}_{1}=0.32\right.$ to 055$)$, as well as that of the standard TRW chronologies ( $r_{1}=0.45,0.50$ and 0.45 for TUIM, SON and SHIRA respectively) is significantly greater than zero. In contrast, the residual chronologies, by design, have approximately zero autocorrelation. Lag-1 (years) autocorrelation of monthly air temperatures is relatively low $\left(\mathrm{r}_{1} \leq 0.31\right)$ for all months, and monthly precipitation has close to zero autocorrelation (Supplementary Table S2).

The lake parameter $\Delta L$ is significantly correlated not only with current 12-month (JulyJune) precipitation (last column, Table 2), but also with 12-month precipitation at lags of several 
1

2

years from $\Delta L$. Maximum correlations are observed at lags of 1, 2, 3 and 8 years: $r_{-1}=0.28(\mathrm{p}<$ $0.05), r_{-2}=0.26(\mathrm{p}<0.05), r_{-3}=0.22(\mathrm{p}=0.08)$, and $r_{-8}=0.29(\mathrm{p}<0.05)$. The lagged relationship is evident in time series plots smoothed with an 11-year cubic spline (Fig. 6d). These plots show smoothed precipitation leading smoothed $\Delta L$ by several years; the maximum correlation between the smoothed curves is at a 2-year lag $\left(r_{-2}=0.75, \mathrm{p}<0.01\right)$. The smoothed curves of $\Delta L$ and precipitation also underscore large-amplitude hydroclimatic variation on the decadal scale; a sinusoidal pattern with an average period of about 17 years is observed in both series: 1) distances between consecutive maximums / minimums of smoothed curves are $10 \ldots 24$ years and $14 \ldots 20$ years for $\Delta L$ and precipitation respectively with their mean values of 16.7 and 17.2 years; 2) curve of cross-correlation coefficients between smoothed $\Delta L$ and precipitation with different lags also has sine-like pattern with $\sim 17$-year mean distance between its consecutive maximums / minimums.

Fluctuations at wavelengths $15-20$ years can also be seen in the Z-sum tree-ring chronology, although in this series they are imbedded in even larger-amplitude variations at the century time scale (Fig. 6c). The recent part of the Z-sum series is broadly synchronous with the two detrended lake level series, though correlations are significant only for $L_{\text {res } 3}$ (Supplementary, Table S3). The Z-sum series roughly leads $L_{\text {res } 1}$ and $L_{\text {res } 3}$ by about two years (Fig. 6c).

The potential for statistical extension of the record of annual change in Lake Shira water level from tree rings is summarized by regression of $\Delta L$ on the standard regional Shira tree-ring chronology (std) (Fig. 6e). The highly significant $(r=0.60, p<0.01)$ relationship between these variables appears to be approximately linear, perhaps with increasing scatter toward the higher water levels. The tree-ring series explains $36 \%$ of $\Delta L$ variance over the 1936-2012 calibration period. Predicted $\Delta L$ by the regression model is positive $(+8.12 \mathrm{~cm})$ for TRW indices close to unity, while predicted $\Delta L$ is negative $(-21.37 \mathrm{~cm})$ for conditions most unfavorable for tree growth. 
2 the positive trend discussed earlier (Fig. 2a). Water-level change tends not only to be positive,

3 but also highly variable from year to year, with a standard deviation $(19.55 \mathrm{~cm})$ almost three

4 times the mean $(6.78 \mathrm{~cm})$.

5 


\section{Discussion}

2 The pattern of climatic response in larch radial growth reported in this study is typical for the

3 forest of southern Siberia (Magda and Vaganov 2006; Knorre et al. 2010; Babushkina et al.

4 2011; Magda et al. 2011). By that we mean that growth of trees is limited by available moisture

5 and there is a 1) positive influence of previous year's fall precipitation, 2) positive influence of

6 current year's May-June precipitation, 3) negative influence of current year's high temperatures

7 during the months of June and July on the radial growth of trees. Novel to this study is that TRW

8 is found to be related not only to climatic conditions of specific months, but to lake-level change,

9 an important integral hydrological parameter.

10 Precipitation in the second half of the year affects tree growth through the supply of nutrients accumulated by the tree for annual increment growth of the next year. This process of accumulation is especially important in our study because larch is a deciduous species: food reserves are vital to the full renewal of needles at the beginning of the growing season (Schulze et al. 2005). The negative influence of temperature in the warm season on TRW is indirect, i.e. high temperature favoring increased evapotranspiration and reduced humidity of both ambient air and soil. It is known that snow cover serves as a heat insulating layer, which protects the soil from freezing in winter and also serves as an additional source of soil moisture as the snow melts in the spring (Nikolaev and Skachkov 2011, 2012). Winter accounts for only 6-14\% of the annual total precipitation in our study area. The snow cover becomes fully set and increases in thickness at the highest rate in November, which explains the positive dependence of TRW on precipitation during this month (Babushkina and Belokopytova 2014).

Previous studies have shown that largest part of the annual ring (up to 75\%) for larch in southern Siberia forms during late May - June (Babushkina et al. 2010; Vaganov et al. 2011). This timing explains the diminished influence of external conditions in current July on the width 
1

of the ring. Larch TRW in our study area accordingly reflects an environmental signal for previous July to current June, and primarily responds to moisture.

Instrumentally recorded dynamics of Lake Shira level can be divided into three components: trend, decadal oscillations and year-to-year variability. Lake level has a strong positive trend, accounting for $67 \%$ or $87 \%$ of the variance in the annual time series for June (Fig. 2a). This trend is not clearly climate-driven, since there are no significant trends in annual precipitation or its seasonal distribution over the period of instrumental data. Moreover, the correlation between annual precipitation and water level before detrending is negative (Table 2). Warm-season temperature has a positive trend $(\mathrm{r}=0.56, \mathrm{~N}=47, \mathrm{p}<0.001)$, which is inconsistent with the water-level trend because warming would contribute to increased evapotranspiration (decreased lake water level). Warming in the cool season could lead to a greater percentage of the cool-season precipitation as rain rather than snow, and might contribute to positive trend in the amount of runoff reaching Lake Shira: precipitation as rain runs off immediately to the lake while temperatures are cool and the evaporation rate is low, while precipitation as snow is subject to higher rates of evaporation when melting begins the following spring. While precipitation in the coldest months, November to March, does have a significant positive trend ( $r$ $=0.305, N=46, p<0.05)$, the study area receives only $9.8 \%$ of the total annual precipitation during that time interval. Precipitation during months the temperature crosses zero (March-April and October-November), when snow cover starts to form or snow melting begins, respectively, has no significant trend. The observed trends just described and the small contribution of the cold season to annual precipitation suggest that changes in cold-season climate have likely been of minor importance to the dynamics of the lake level.

We suggest that the upward trend in Lake Shira level is related to the continual groundwater inflow from Lake Itkul. This trend may be driven by climatic changes (e.g., in snowpack or snowmelt) not represented well by precipitation and temperature records analyzed here. Our rough estimate using typical hydrologic parameters (Bear 1972) showed that 
1

2

groundwater from Lake Itkul might reach Lake Shira in 7-8 years. The presence of a significant positive correlation of Lake Shira $\Delta L$ with regional precipitation with an 8-year lag also gives support to this hypothesis, since Itkul is a flow-through lake that integrates the current precipitation from its watershed and partly from the Tuim River watershed. In any case, the increase of the Lake Shira level is relatively stationary and its contribution to $\Delta L$ in the first approximation can be mathematically described as addition of a constant.

Autocorrelation in lake-level change can arise from many different sources, including the regulating influence of the groundwater system in extending the time required by precipitation in various parts of the watershed to reach the lake. The lag in response can be many years in some systems (Gillies et al. 2011, 2015). For Lake Shira, $\Delta L$ is significantly correlated with precipitation in the preceding three years, and smoothed plots show a delay of about two years in decadal fluctuations (Fig.6c, d). The closed basin is a dynamic system, with important lagged relationships between lake water level variations to precipitation and tree rings.

The sine wave pattern of smoothed time series of level difference and precipitation plotted in Fig 6d suggests a 17-year quasi-periodic variation in moisture regime. This rhythm, though not a regular cycle, is important in terms of its high amplitude relative to inter-annual variation. We can suggest that drivers of this quasi-periodic variation may be atmospheric oscillations of global scale, such as the Arctic Oscillation, North Pacific Oscillation or Siberian High, but more research on this topic is needed.

A simple regression model for annual lake-level difference as a function of radial growth indices of larch gives additional information on the hydrological regime of the study area. The modeled relationship Fig. 6e) is significant because the main mechanisms of gain/loss of water to/from the soil and to and to/from the surface of the lake is very similar: gains are from precipitation (including winter precipitation as snow) and the losses are due to evaporation, especially at high temperatures. The tree-ring response is supported by the correlation functions in Fig 5, and the similarity in lake level and tree-growth responses is supported by the time series 
1 plots and regression results in Fig. 6. For extremely adverse conditions, when incremental tree

2 growth is theoretically zero, the predicted annual lake-level change is $-21.37 \mathrm{~cm}$; this drop in

3 level corresponds approximately to a loss of $7693 \times 10^{3} \mathrm{~m}^{3}$ of water from the lake. For

4 comparison, Savichev et al. (2015) estimated the maximum value of the inflow of water from

$5 \quad$ Lake Itkul as $\left.6791 \times 10^{3} \mathrm{~m}^{3}\right)$.

Such a drop in water level would of course correspond to an extremely dry year, which would not only reduce the inflow to the lakes but also increase the loss of water due to evaporation. A series of such years could drastically reduce the level of the Lake Shira and result in increased lake salinity. Such an event of increased salinity at the beginning of the 20th century was noted by Rogozin et al. (2010), and is consistent with the low tree growth at that time in our larch chronology (Fig. 6c). During the on-going five decades the gain of water to Lake Shira exceeds the loss, resulting in an annual level increase of $\sim 6-8 \mathrm{~cm}$ per year. The real reasons for this period being so favorable in terms of water content should be investigated in more detail, using both data from sediments of Lake Shira and Lake Itkul and information on winter snow variability in the foothills areas that feed the lake with snowmelt. We are confident that the long tree-ring chronologies that successfully capture lake-level variations, one of the main components of the water balance, are a good tool both for improved hydrologic modeling and for hydrologic prediction in this closed-basin system.

Our results indicate that the 12-month difference $\Delta L$ of Lake Shira water level reflects the dynamics of the hydrological regime of the Bele-Shira closed basin. The same variable, $\Delta L$, is highly correlated with chronologies of radial growth of woody plants, and can be viewed also as an indicator of plant water stress. Accordingly, TRW records have the potential for temporal extension, or reconstruction of annual-to-decadal fluctuations of lake level. Caution should be exercised for reconstruction of lower-frequency oscillations: if indeed there is a long-term influence of the inflow from Lake Itkul, then proper reconstruction should employ independent data or a simple filtration model in addition to the tree-ring data. We plan to use this approach in 
1 future studies. Future studies will also address the sensitivity of tree-ring inferences on low-

2 frequency changes in lake dynamics to the standardization choices in development of the tree-

3 ring chronologies. This is important, as low-frequency climatic signals can be removed from

4 ring-width records in the process of detrending (Fritts 1976).

5 The essentially synchronous changes in the cumulative function of growth of larch with the

6 level of Lake Shira support such reconstruction, while emphasizing the need to fully understand

7 the dynamics of water movement through the hydrologic system at long and short timescales. As

8 Larix sibirica is widely distributed in the basins of the $\mathrm{Ob}$ and Yenisei Rivers, our results are of

9 broader significance for dendrohydrological potential over semi-arid parts of two of the world's

10 largest river systems.

11 


\section{Conclusions}

2 Because the Bele-Shira closed basin includes forest lands, agricultural lands and

3 protected areas, the results obtained in this study can serve a variety of practical applications.

4 First, it is possible to reconstruct interannual and decadal variation of hydrological regime during

5 last few centuries through regression models using tree-ring chronologies themselves (DeRose et

6 al. 2014) or the dynamics of climatic variables recovered using tree-ring chronologies (Quinn

7 and Sellinger 2006). Second, it is possible to predict the moisture regime of this territory for

8 future climate change scenarios (Kopytkovskiy et al. 2015). Finally, since tree-ring chronologies

9 may be considered as a dynamic characteristic of the condition and productivity of the

10 ecosystem, the results of prediction may be employed in regional environmental management for

11 conservation planning and more optimal forest management and agriculture management.

\section{Acknowledgements}

14 This study was funded by the Russian Foundation for Basic Research and the Republic of

15 Khakassia according to the research projects No. 14-44-04043 and No. 15-05-01666. We also

16 thank anonymous reviewers and editor Wolfgang Cramer for their helpful comments. 


\section{$1 \quad$ References}

2 Alisov BP (1956) Climate of the USSR. Moscow State University, Moscow. (in Russian)

3 Babushkina EA, Vaganov EA, Silkin PP (2010) Influence of the climatic factors on the cell

4

5

6

7

8

9

10 structure of the tree-rings of conifers growing in different topoecological conditions of the forest-steppe zone of Khakasia. Journal of the Siberian Federal University (Biology) 3: 159-176. (in Russian)

Babushkina EA, Knorre AA, Vaganov EA, Bryukhanova MV (2011) Transformation of climatic response in radial increment of trees depending on topoecological conditions of their occurrence. Geography and Natural Resources 32(1): 80-86. doi:10.1134/S1875372811010148.

Babushkina EA, Belokopytova LV (2014) Climatic signal in radial increment of conifers in forest-steppe of Southern Siberia and its dependence on local growing conditions. Russian Journal of Ecology 45: 325-332. doi: 10.1134/S1067413614050038

Bazhenova OI, Tyumentseva EM (2010) The structure of contemporary denudation in the steppes of the Minusinskaya depression. Geography and Natural Resources 4 (31): 362369. doi: 10.1016/j.gnr.2010.11.010

Bear J (1972) Dynamics of Fluids in Porous Media. Dover Publications, New York

Biondi F, Strachan S (2012) Dendrohydrology in 2050: Challenges and Opportunities. In: Grayman WM, Loucks DP, Saito L (eds.) Toward a Sustainable Water Future. ASCE, Reston, pp 355-362

Bradley RS (2009) Holocene Perspectives on Future Climate Change. In: Battarbee RW, Binney HA (eds.) Natural Climate Variability and Global Warming: A Holocene Perspective. Wiley-Blackwell, London, pp. 254-268

Cook ER, Peters K (1981) The smoothing spline: A new approach to standardizing forest interior tree-ring width series for dendroclimatic studies. Tree-Ring Bulletin 41: 45-53. 
1 Cook E, Briffa K (1990) Data Analysis. In: Cook ER, Kairiukstis LA (eds.) Methods of

2 Dendrochronology: Applications in the Environmental Sciences. Kluwer Academic

3 Publishers, Dordrecht, pp. 97-162

4 Cook ER, Krusic PJ (2005) Program ARSTAN, Version

41d. http://www.ldeo.columbia.edu/tree-ring-laboratory/resources/software

DeRose RJ, Wang S-Y, Buckley BM, Bekker MF (2014) Tree-ring reconstruction of the level of Great Salt Lake, USA. The Holocene 24 (7): 805-813. doi: 10.1177/0959683614530441

Fritts HC (1976) Tree rings and climate. Elsevier Inc, London, New-York, San Francisco

Giadrossich F, Niedda M, Cohen D, Pirastru M (2015) Evaporation in a Mediterranean environment by energy budget and Penman methods, Lake Baratz, Sardinia, Italy. Hydrol. Earth Syst. Sci. 19: 2451-2468.doi: 10.5194/hess-19-2451-2015

Gillies RR, Chung O-Y, Wang S-Y, Kokoszka P (2011) Incorporation of Pacific SSTs in a time series model toward a longer-term forecast for the Great Salt Lake elevation. Journal of Hydrometeorology 12(3): 474-480. doi: 10.1175/2010JHM1352.1.

Gillies RR, Chung O-Y, Simon Wang S-Y, DeRose RJ, Sun Y (2015) Added value from 576 years of tree-ring records in the prediction of the Great Salt Lake level. Journal of Hydrology 529(3): 962-968.doi: 10.1016/j.jhydrol.2015.08.058.

Holmes RL (1999) Dendrochronology program library. Users manual. Laboratory of Tree-Ring Research, University of Arizona.

Knorre AA, Siegwolf RTW, Saurer M, Sidorova OV, Vaganov EA, Kirdyanov AV (2010) Twentieth century trends in tree ring stable isotopes $\delta^{13} \mathrm{C}$ and $\delta^{18} \mathrm{O}$ of Larix sibirica under dry conditions in the forest steppe in Siberia. Journal of Geophysical Research 115, G03002. doi: 10.1029/2009JG000930

Kopytkovskiy M, Geza M, McCray J (2015) Climate-change impacts on water resources and hydropower potential in the Upper Colorado River Basin. J Hydrol Reg Stud 3: 473-493. 
Magda VN, Vaganov EA (2006) Climatic response of the tree growth in the mountain foreststeppes of Altai-Sayan region. Izvestiya RAN (Geography) 5: 92-100. (in Russian)

Magda VN, Block J, Oidupaa OC, Vaganov EA (2011) Extraction of the climatic signal for moisture from tree-ring chronologies of Altai-Sayan mountain forest-steppes. Contemporary Problems of Ecology 4: 716-724. doi: 10.1134/S1995425511070034

Maksimov AA (1989) Natural cycles. The reasons for cyclicities of ecological processes. Nauka, Leningrad (in Russian)

Matskovsky VV, Dolgova EA, Solomina ON (2010) Teberda River runoff variability AD 18502005 based on tree ring reconstruction Northern Caucasus, Russia. IOP Conference Series: Earth and Environmental Science 1 (9): [6 p.]. doi: 10.1088/1755-1315/9/1/012017

Meko DM, Therrell MD, Baisan CH, Hughes MK (2001) Sacramento River flow reconstructed to A.D. 869 from tree rings. Journal of the American Water Resources Association 37(4): 1029-1039.

Meko DM (2006) Tree-ring inferences on water-level fluctuations of Lake Athabasca. Canadian Water Resources Journal 4 (31): 229-248.

Meko DM, Woodhouse CA (2011) Application of streamflow reconstruction to water resources management. In: Hughes MK, Swetnam TW, Diaz HF (eds.) Dendroclimatology, Progress and Prospects, Developments in Paleoenvironmental Research. Springer, Dordrecht, pp $231-261$

Nikolaev AN, Skachkov YB (2011) Influence of the dynamics of the snow cover on growth and development of forests in Central Yakutia. Kriosfera Zemli 3: 71-80. (in Russian)

Nikolaev AN, Skachkov YB (2012) Influence of snow cover and temperature regime of permafrost soils on radial growth of trees from Central Yakutia. Journal of Siberian Federal University (Biology) 1: 43-51. (in Russian)

Palmer WC (1965) Meteorological Drought. D.C., Washington 
1 Quinn FH, Sellinger CE (2006) A reconstruction of Lake Michigan-Huron water levels derived from tree ring chronologies for the period 1600-1961. Journal of Great Lakes Research 32: 29-39.

Rinn F (2011) TSAP Win. Time Series Analysis and Presentation for Dendrochronology and Related Applications. Version 4/64 for Microsoft Windows: User Reference. Heidelberg

Rogozin DY, Genova SV, Gulati RD, Degermendzhy AG (2010) Some generalizations on stratification and vertical mixing in meromictic Lake Shira, Russia, in the period 20022009. Aquatic Ecology 44 (3): 485-496.

Savichev OG, Guseva NV, Abdullaev BD (2015) Water balance of the lake system Shira-Itkul, Khakasia. Vestnik Tomskogo gosadarstvennogo universiteta 391: 214-219. (in Russian)

Schulze ED, Beck E, Müller-Hohenstein K (2005) Plant Ecology. Springer, Berlin, Heidelberg Selyaniniov GT (1958) Principles of agroclimatic regional planning in USSR. In: Davitaya FF, Shulgina AI (eds.) Voprosi agroklimaticjeskogo rayonirovania SSSR. Ministry of Agriculture of the USSR, Moscow, pp 18-26

Shanahan TM, Overpeck JT, Sholz C, Sharpe E, Arko J (2007) Simulating the response of a closed basin lake to recent climate changes in tropical West Africa (Lake Bosumtwi, Ghana), Hydrol. Processes 21: 1678-1691, doi:10.1002/hyp.6359

Shnitnikov AV (1969) Intracentennial variability of the components of general moisture availability. Nauka, Leningrad. (in Russian)

Vaganov EA, Anchukaitis KJ, Evans MN (2011) How well understood are the processes that create dendroclimatic records? A mechanistic model of the climatic control on conifer treering growth dynamics. In: Hughes MK, Swetnam TW, Diaz HF (eds.) Dendroclimatology, Progress and Prospects, Developments in Paleoenvironmental Research. Springer, Dordrecht, pp 37-75 
1 Wang S-Y, Gillies RR, Reichler T (2012) Multidecadal drought cycles in the Great Basin

2 recorded by the Great Salt Lake: Modulation from a transition-phase

3 teleconnection. Journal of Climate 25: 1711-1721. doi: 10.1175/2011JCLI4225.1.

4 Wigley TML, Briffa KR, Jones PD (1984) On the average value of correlated time series, with 5 application in dendrochronology and hydrometeorology. J. of Climate and Applied

6 Meteorology 23: 201-213.

7 Wilks, DS (1995) Statistical methods in the atmospheric sciences. Academic Press, San Diego 8 


\section{TABLES}

2

3 Table 1. Statistics of standardized tree-ring width chronologies.

4

\begin{tabular}{|c|c|c|c|}
\hline \multirow{2}{*}{ Statistics } & \multicolumn{3}{|c|}{ Chronology $^{\mathrm{a}}$} \\
\hline & TUIM & SON & SHIRA \\
\hline Covered period, years & $1719-2013$ & $1864-2013$ & $1719-2013$ \\
\hline Inter-series correlation coefficient $(\bar{R})$ & $\frac{0.66}{0.66}$ & $\frac{0.53}{0.55}$ & $\frac{0.64}{0.65}$ \\
\hline Expressed population signal $^{\mathrm{b}}$ (EPS) & $\frac{0.99}{0.99}$ & $\frac{0.95}{0.94}$ & $\frac{0.99}{0.99}$ \\
\hline Sensitivity $(S)$ & $\frac{0.43}{0.47}$ & $\frac{0.28}{0.32}$ & $\frac{0.42}{0.44}$ \\
\hline
\end{tabular}

5

$6 \quad{ }^{a}$ Numerator indicates statistic for standard chronology, the denominator for residual chronology

$7 \quad$ bPS listed is for year 1936, earliest year used for climate relationships in this paper

8 
1 Table 2. Relationships between the Shira lake-level variables, larch tree ring width chronologies 2 and July-June precipitation ${ }^{\mathrm{a}}$.

3

\begin{tabular}{|c|c|c|c|c|c|}
\hline & \begin{tabular}{|} 
Level above \\
zero mark of \\
station in June \\
$(L)$
\end{tabular} & \begin{tabular}{|c|} 
Level \\
deviation from \\
linear trend in \\
June $\left(L_{r e s 1}\right)$
\end{tabular} & $\begin{array}{c}\text { Level deviation } \\
\text { from } \\
\text { polynomial } \\
\text { trend in June } \\
\left(L_{r e s 3}\right)\end{array}$ & $\begin{array}{c}\text { First annual } \\
\text { difference of level } \\
\text { from previous to } \\
\text { current June }(\Delta L)\end{array}$ & $\begin{array}{l}\text { Annual } \\
\text { precipitation sum } \\
\text { from previous July } \\
\text { to current June }(P)\end{array}$ \\
\hline $\begin{array}{c}\text { SHIRA } \\
\text { std }\end{array}$ & $-0.29^{*}$ & 0.05 & $-0.36^{*}$ & $0.64^{*}$ & $0.46^{*}$ \\
\hline $\begin{array}{c}\text { SON } \\
\text { std }\end{array}$ & -0.16 & 0.06 & -0.22 & $0.59^{*}$ & $0.48^{*}$ \\
\hline $\begin{array}{c}\text { TUIM } \\
\text { std }\end{array}$ & $-0.30^{*}$ & 0.04 & $-0.38^{*}$ & $0.63^{*}$ & $0.44^{*}$ \\
\hline $\begin{array}{c}\text { SHIRA } \\
\text { res }\end{array}$ & -0.21 & -0.04 & $-0.26^{*}$ & $0.55^{*}$ & $0.57^{*}$ \\
\hline $\begin{array}{c}\text { SON } \\
\text { res }\end{array}$ & -0.10 & -0.02 & -0.17 & $0.54^{*}$ & $0.60^{*}$ \\
\hline $\begin{array}{c}\text { TUIM } \\
\text { res }\end{array}$ & -0.21 & -0.04 & $-0.28^{*}$ & $0.54^{*}$ & $0.55^{*}$ \\
\hline$P$ & $-0.29^{*}$ & -0.13 & -0.09 & $0.55^{*}$ & - \\
\hline
\end{tabular}

4

$5 \quad{ }^{a}$ Correlations are for the analysis period 1937-2012 (number of years $N$ varies between 70 and 74 years

6 due to gaps in observations). Correlations marked with an asterisk are significant at $p<0.05$. 
3 Fig. 1 Study basin and data locations. Boundary of the Bele-Shira closed basin - bold blue

4 dashed line, main settlements - orange areas, meteorological station - black circle, hydrological

5 stations - black diamonds, dendrochronological sites - black triangles. Directions of seasonal

6 water exchange between basins of Lake Itkul and the Tuim river through temporary surface watercourses are marked with solid arrows. Probable path of groundwater movement from Lake

8 Itkul to Lake Shira (Savichev et al., 2015) is marked with dotted arrows.

9

Fig. 2 Measured and derived hydrological variables in Bele-Shira closed basin: (a) Lake Shira level $L$ and its fitted linear $\left(L_{1}-\right.$ dashed), and third-degree polynomial $\left(L_{3}-\right.$ solid $)$ trends; (b) long-term (1967-2012) monthly means of river discharge $Q$ (Tuim - dashed line, Son - dotted line), monthly difference of the lake Shira level $\Delta L m$ (solid line), and monthly precipitation $P$ (bars); (c) annual first-difference of Lake Shira level $\Delta L$ (solid line) and Lake Shira level departures from linear and cubic trends $L_{r e s 1}$ and $L_{\text {res } 3}$ (dashed and dotted lines respectively). All plots in panels (a) and (c) are for month of June. Curve $\Delta L m$ in (b) is average monthly change of level (e.g., value for June is change of average water-level from May to June). station. Means and standard deviations of the Selyaninov hydrothermal coefficient (HTC) are shown for months with air temperatures above $10^{\circ} \mathrm{C}$. Analysis period is 1967-2012. trees) in each year. (a) TUIM: separate chronologies of cores and sections and combined local chronology (b) SON: separate chronologies of two sites and combined local chronology. (c) 
1 have estimated population signal EPS $>0.85$ during time period to the right of red dashed

2 vertical line.

3

4 Fig. 5 Pearson correlation coefficients of residual tree-ring width chronologies with the climatic

5 variables of individual months and longer periods: (a) precipitation; (b) temperature; (c)

6 Selyaninov hydrothermal coefficient. Significant $(\mathrm{p}<0.05)$ correlation coefficients are marked

7 with plus symbols (+). Asterisks indicate months or monthly groupings for the year preceding

8 the growth year of trees.

9

10 Fig. 6 Interannual dynamics of the main variables reflecting moisture regime of study area and 11 standardized regional tree-ring width chronologies: (a) Lake Shira annual water-level difference $12 \Delta L$ (June) and standard regional chronology; (b) annual precipitation P (July-June) and residual 13 regional chronology; (c) Lake Shira water-level departures from linear and cubic trends $L_{\text {res1 }}$ and $14 L_{\text {res3 }}$ and regional chronology of Z-scores sum; (d) Lake Shira annual water-level difference $\Delta L$, 15 the annual amount of precipitation $\mathrm{P}$ and their 11-year cubic spline smoothed curves, distances 16 between consecutive maximums / minimums are shown for both smoothed curves; (e)

17 dependence of the lake Shira annual level difference $\Delta L$ (June) on standard regional chronology 18 from the (a) panel and its linear regression approximation function. 


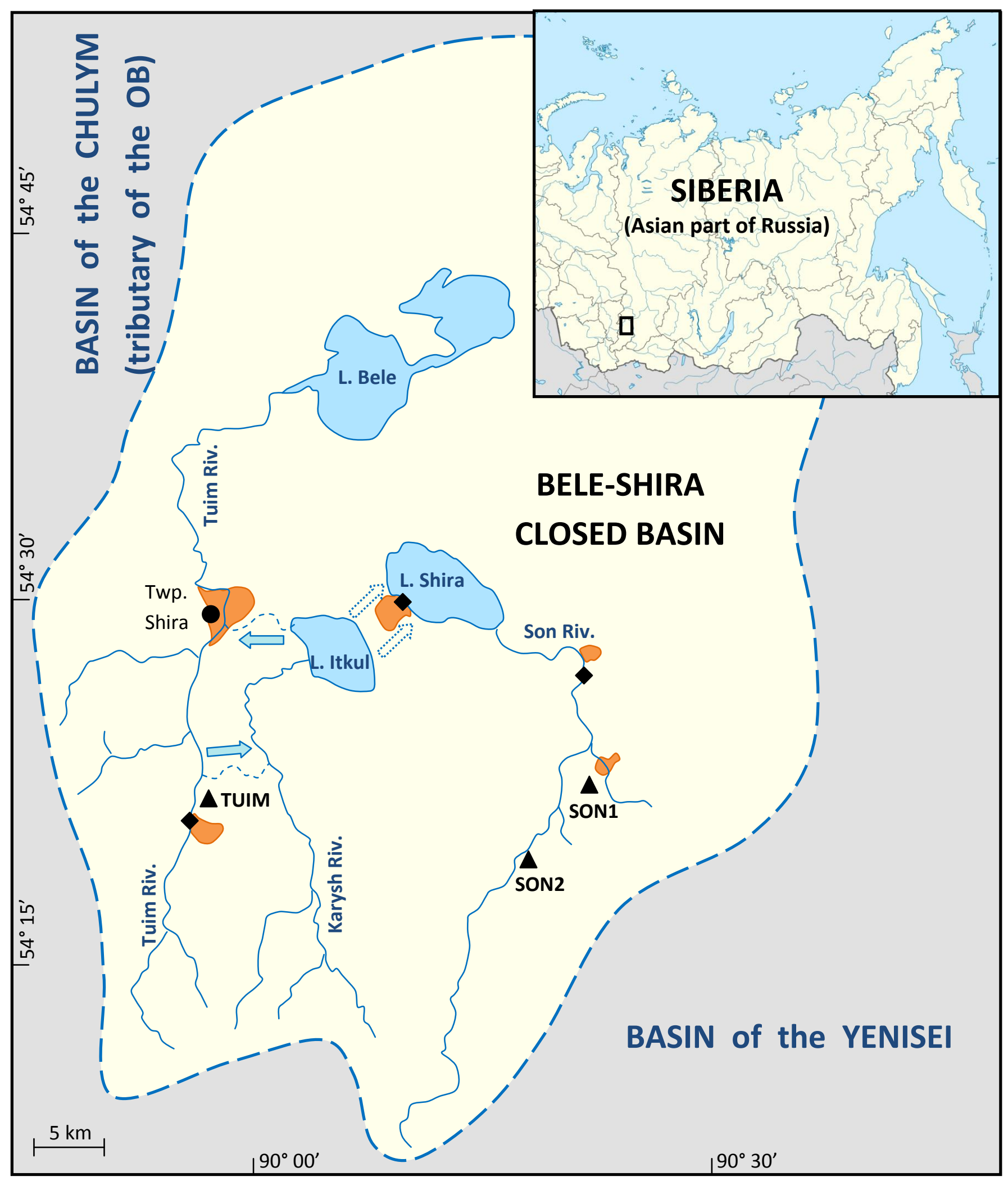

Figure 1. 


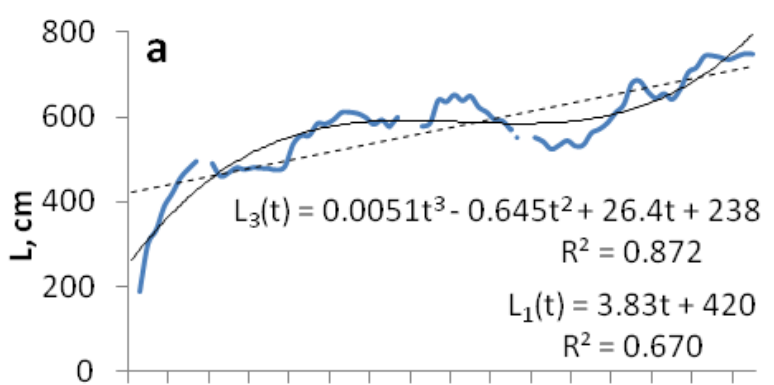

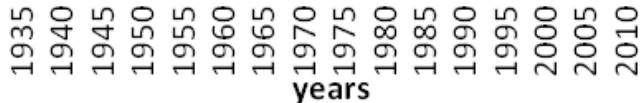

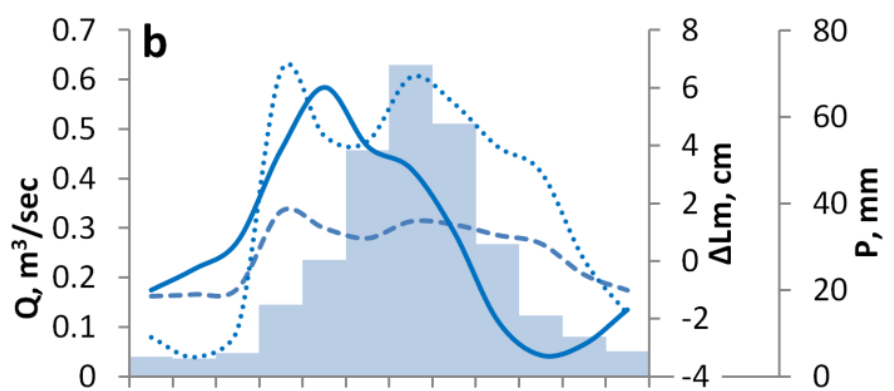

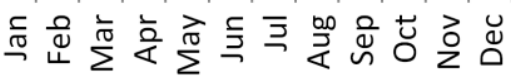
months

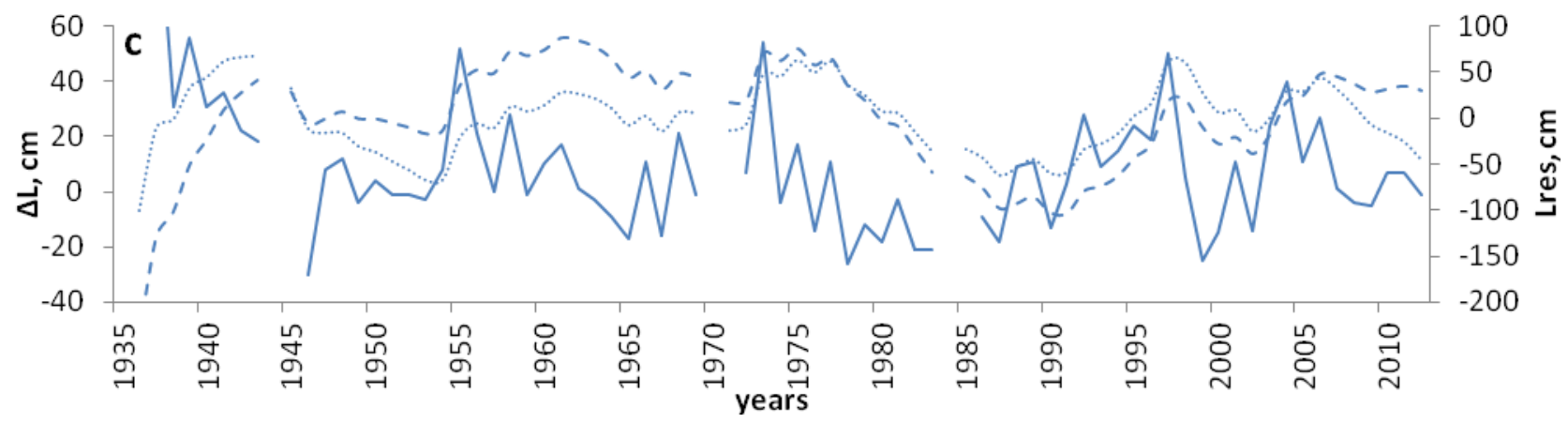

Figure 2. 


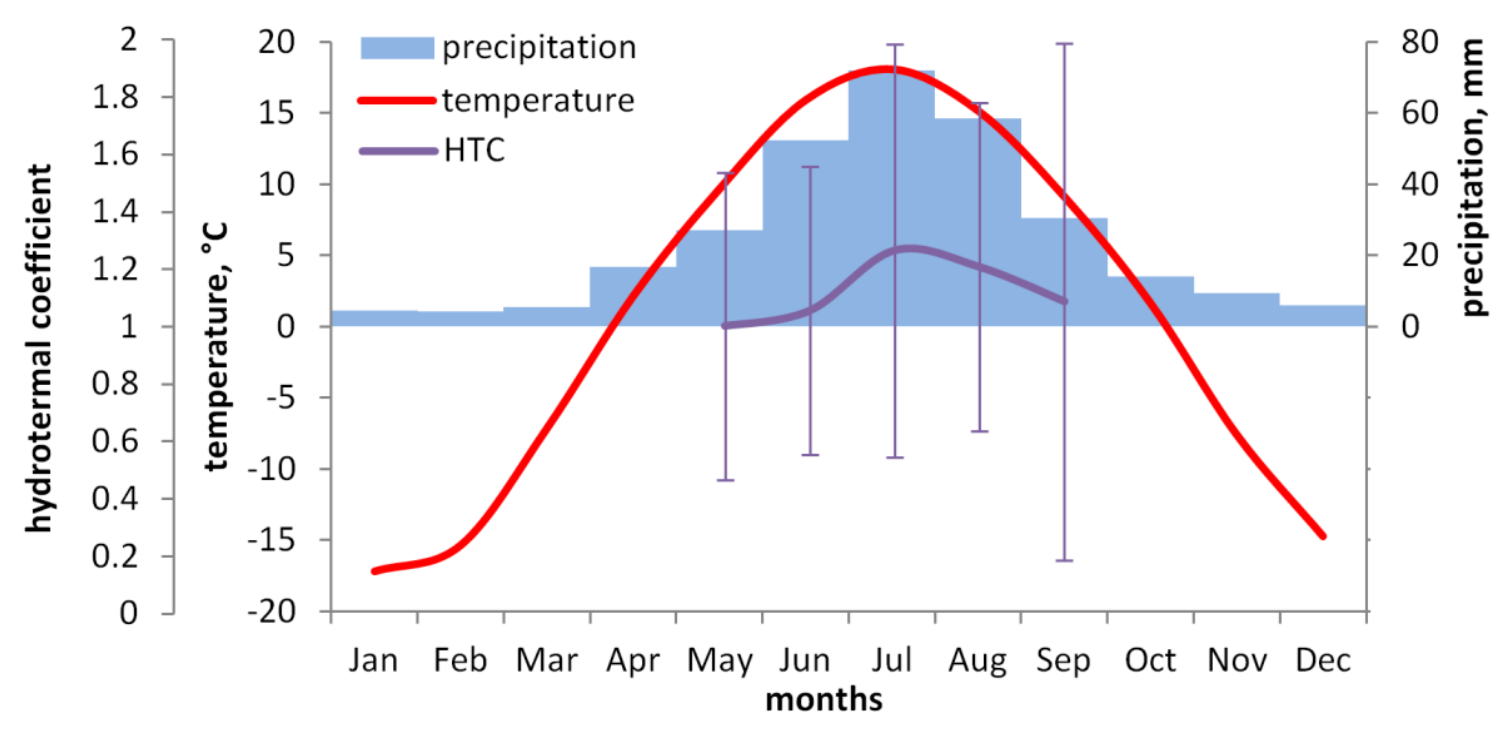

2

Figure 3. 

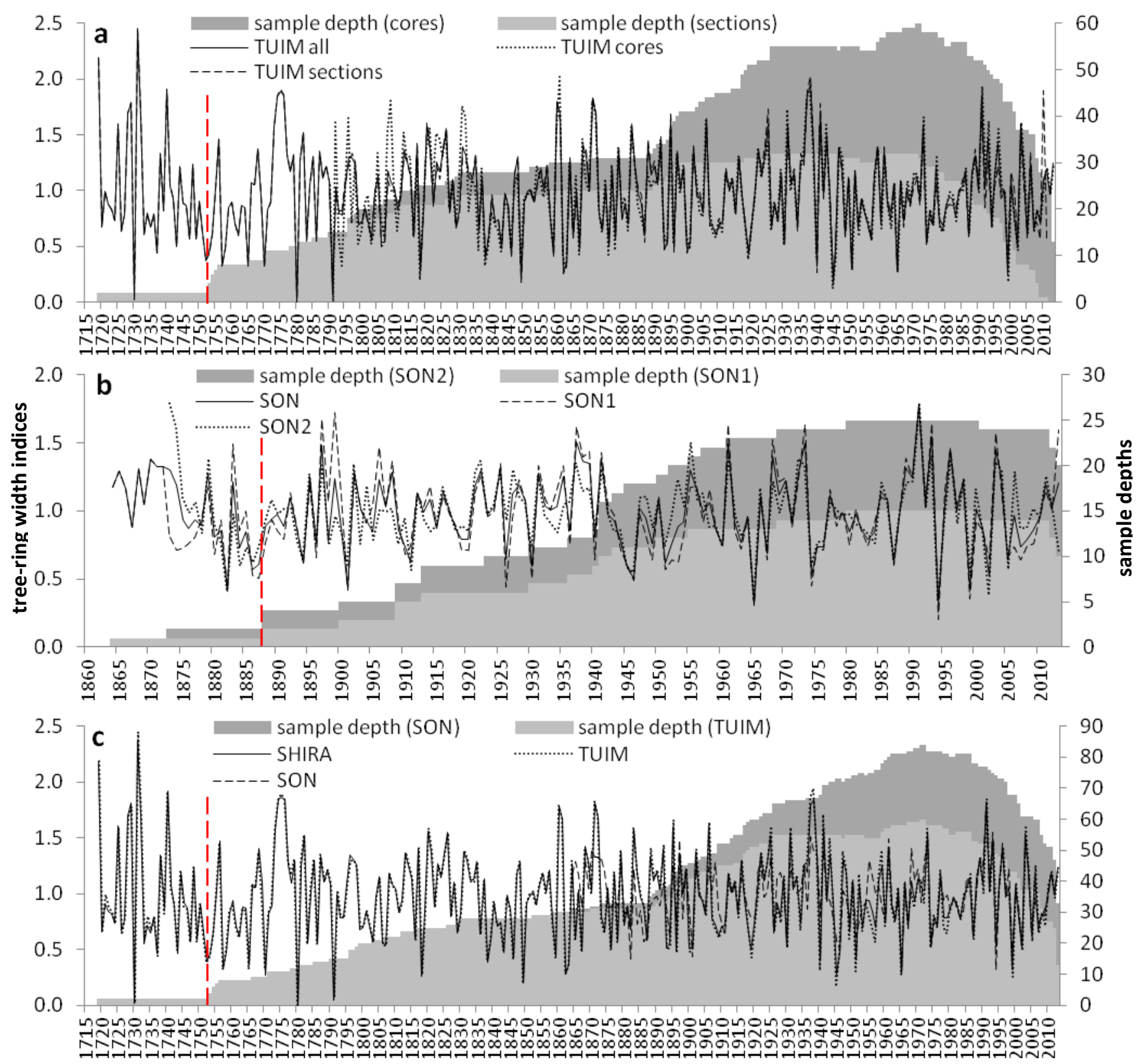

Figure 4. 

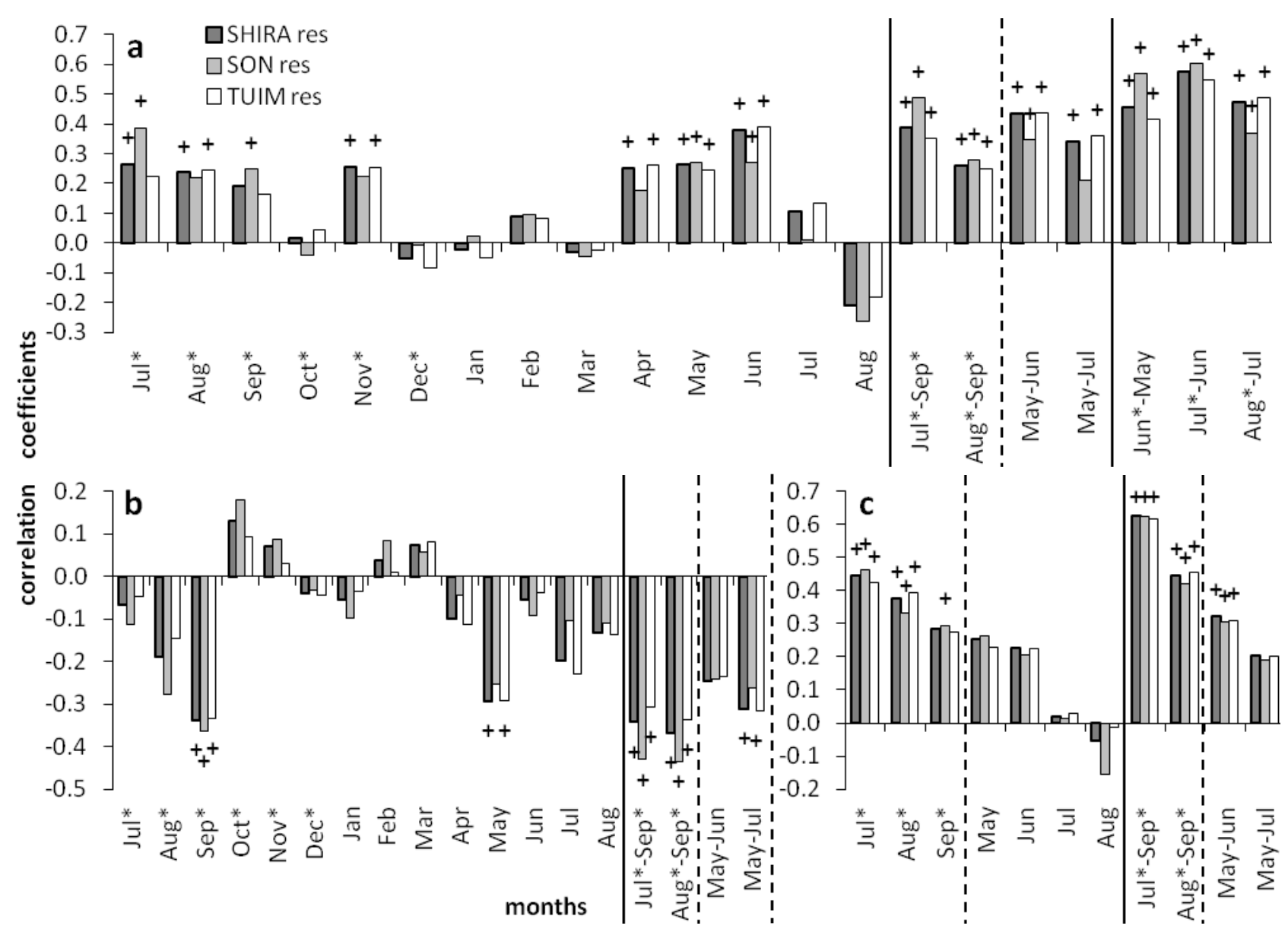

Figure 5. 


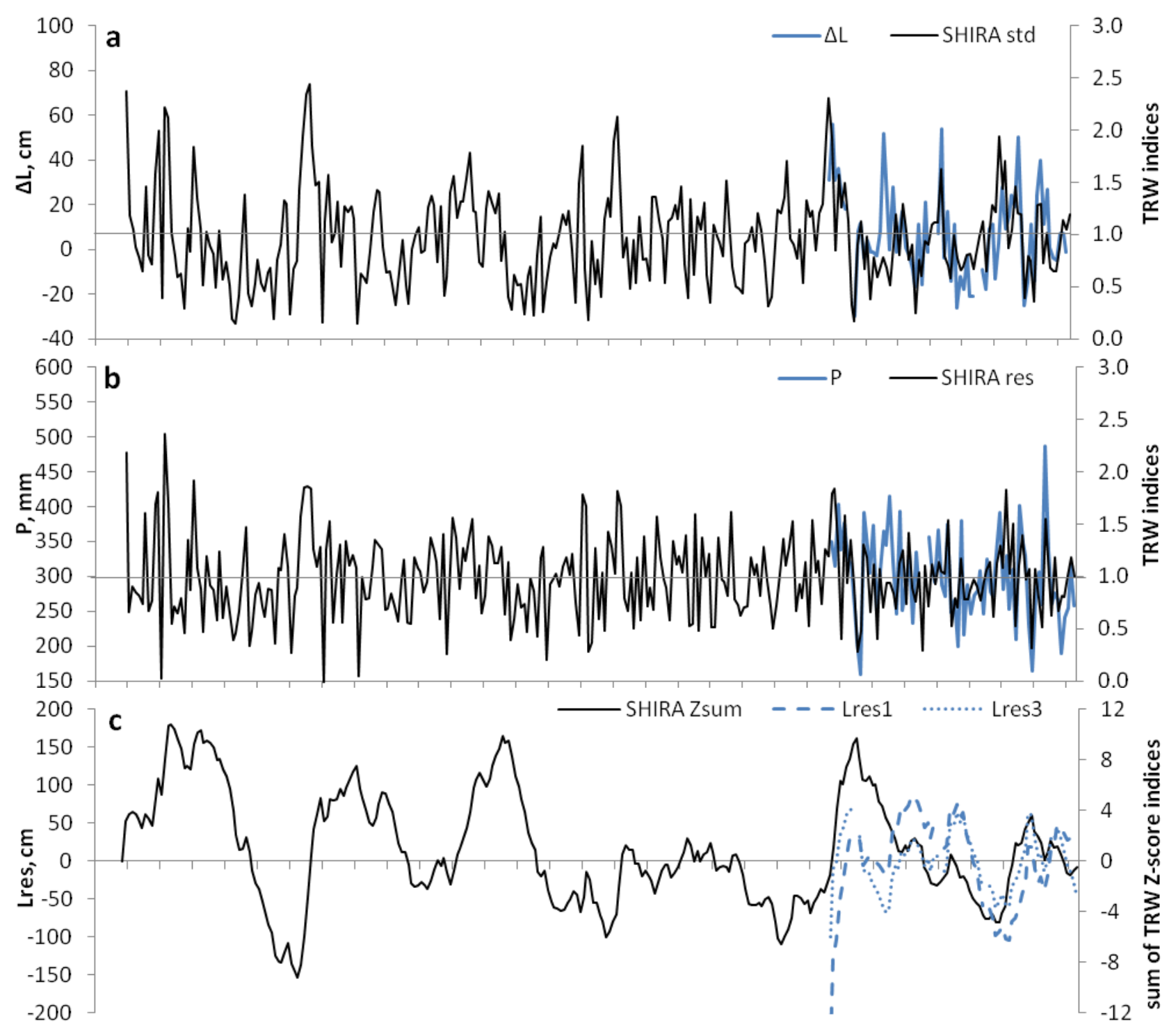

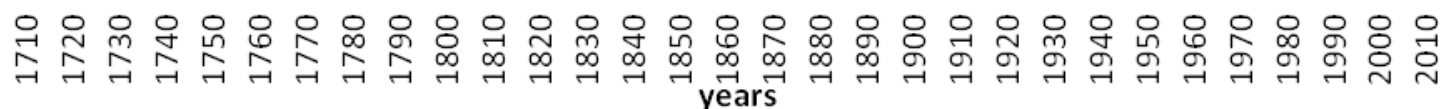

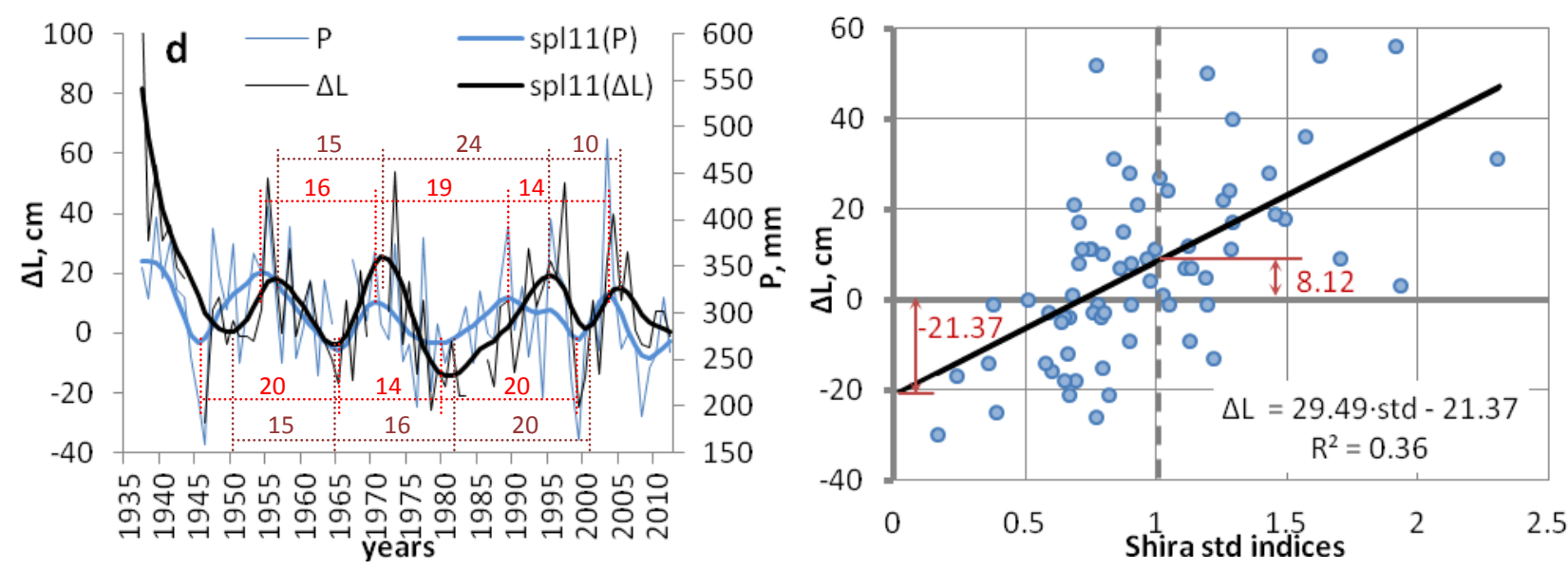

Figure 6. 


\section{SUPPLEMENTARY MATERIALS}

2 Table S1. Pearson correlation coefficients* between tree-ring width chronologies of different samples.

\begin{tabular}{|l|l|l|l|}
\hline \multirow{2}{*}{ Samples } & Common & \multicolumn{2}{|l|}{ Chronology type } \\
\cline { 3 - 4 } & \multirow{2}{*}{ period } & std & res \\
\hline TUIM cores / TUIM sections & $1790-2011$ & 0.89 & 0.88 \\
\hline SON1 / SON2 & $1873-2013$ & 0.47 & 0.65 \\
\hline TUIM / SON & & & \\
\hline
\end{tabular}

*All correlations are significant at $p<0.05$.

Table S2. First-order autocorrelation coefficients ${ }^{\mathrm{a}}\left(\mathrm{r}_{1}\right)$ of main hydroclimatic variables.

\begin{tabular}{|c|c|c|c|}
\hline Month & $\begin{array}{c}\text { Annual difference of the } \\
\text { Shira Lake level }(\Delta L)\end{array}$ & $\begin{array}{c}\text { Monthly air } \\
\text { temperature }(T)\end{array}$ & $\begin{array}{c}\text { Monthly } \\
\text { precipitation }(P)\end{array}$ \\
\hline Jan & 0.55 & -0.02 & 0.06 \\
\hline Feb & 0.48 & 0.10 & 0.00 \\
\hline Mar & 0.46 & -0.15 & 0.01 \\
\hline Apr & 0.44 & -0.13 & -0.10 \\
\hline May & 0.32 & 0.23 & -0.03 \\
\hline Jun & 0.34 & 0.30 & 0.05 \\
\hline Jul & 0.34 & 0.23 & -0.04 \\
\hline Aug & 0.39 & 0.24 & -0.11 \\
\hline Sep & 0.46 & 0.10 & 0.12 \\
\hline Oct & 0.50 & 0.21 & -0.09 \\
\hline Nov & 0.51 & -0.23 & -0.04 \\
\hline Dec & 0.54 & 0.31 & -0.05 \\
\hline
\end{tabular}

8 a Periods for analysis are 1966-2012 for temperature and 1937-2012 for water-level change and precipitation. For monthly variables, first-order refers to a one-year lag for the particular month of year. 
1 Table S3. Correlations ${ }^{\mathrm{a}}$ between detrended June level of Lake Shira Lake and integral tree-ring width.

\begin{tabular}{|c|c|c|c|}
\hline \multirow{2}{*}{ Lake level series } & \multicolumn{3}{|c|}{ Z-sum chronology } \\
\cline { 2 - 4 } & SHIRA & SON & TUIM \\
\hline after removal of linear trend $\left(L_{\text {res } 1}\right)$ & 0.19 & 0.02 & 0.20 \\
\hline after removal of cubic trend $\left(L_{\text {res } 3}\right)$ & $0.33^{*}$ & $0.49^{*}$ & $0.26^{*}$ \\
\hline
\end{tabular}

3 Correlations marked with an asterisk are significant at $p<0.05$; analysis period is 1936-2012 $(N=77)$. 